\title{
Expression of ARE-binding proteins AUF1 and HuR in follicular adenoma and carcinoma of thyroid gland
}

\author{
B. TROJANOWICZ ${ }^{1, *}$, C. SEKULLA², H. DRALLE², C. HOANG-VU² \\ ${ }^{1}$ Department of Internal Medicine II, Martin-Luther-University Halle-Wittenberg, Germany; ${ }^{2}$ Clinics of General, Visceral and Vascular Surgery, \\ Martin-Luther-University Halle-Wittenberg, Germany
}

*Correspondence: bogusz.trojanowicz@uk-halle.de

Received August 19, 2015 / Accepted November 18, 2015

\begin{abstract}
Both adenylate-uridylate rich elements binding proteins AUF1 and HuR may participate in thyroid carcinoma progression. In this study we investigated the expression of both factors on a protein level with a special focus on follicular adenoma and follicular thyroid carcinoma. By employment of immunofluorescence and western blot on 68 thyroid tissues including 7 goiter, 16 follicular adenoma (4 adenomatous hyperplasia), 19 follicular thyroid carcinomas, 13 papillary thyroid carcinomas and 14 undifferentiated thyroid carcinomas we investigated protein expression of AUF1 and HuR. In addition to previous results we demonstrated that AUF1 and HuR are significantly up-regulated in carcinoma tissues as compared with follicular adenoma or goiter tissues. Furthermore, by evaluation of AUF1 or HuR expression, or combination of both proteins on total tissue lysates, we were able to demonstrate a significant difference between follicular adenoma and follicular thyroid carcinoma.

Overexpression of AUF1 and HuR is a common finding observed in thyroid malignancy. Analysis of the tissues obtained by surgical resection as demonstrated in this study is comparable to a fine needle aspiration and in combination with AUF1/ HuR immuno-analysis may support the conventional immunohistological investigations. The promising results of this study were performed on relatively small collective, but justify future development of a quick thyroid diagnostic test on larger cohort of the patients, especially for thyroid samples which are inadequate for histological examinations.
\end{abstract}

Key words: AUF1, HuR, ARE, thyroid carcinoma, follicular adenoma, FTC

Thyroid cancer represents the most common endocrine malignancy [1]. Current molecular techniques employing genomics and proteomics revealed a rapid progress in identification and application of diagnostic markers for thyroid carcinoma [2]. However due to the different morphological interpretations, sample preparation and standardisation methods significant obstacles in utilisation of thyroid biomarkers are observed. These suggest a clear need to further search for new genes and/or proteins demonstrating diagnostic and/or prognostic potential. Still a growing body of evidence reveals that regulation of mRNA stability may affect thyroid specific functions and participate in processes of thyroid carcinogenesis. This regulation is largely exerted by trace elements such as iron, selenium and iodide, miRNAs and mRNA-binding proteins $[3,4,5,6,7,8]$. Some of mRNA-binding proteins interact specifically with adenylate-uridylate rich elements (ARE) contained in 3' untranslated region (3'-UTR) of target mRNAs [9]. Out of many known ARE-binding proteins two of them, AUF1 and HuR, have been studied most extensively and demonstrated to regulate mRNA stability in vivo. Both proteins were reported to exert opposite effects on target transcripts. HuR is known to enhance their stability and/or translation, while AUF1 which is expressed as four isoforms causes generally the decay of some mRNAs $[10,11,12,13,14,15]$.

The patients with suspicious thyroid nodules are usually submitted to fine needle aspiration (FNA) biopsy as an initial test for histo(cyto)pathological evaluation. Papillary thyroid carcinoma (PTC) which is the most frequent diagnosed type of thyroid cancer is relatively easy to discriminate by employment of FNA biopsy. However in case of follicular thyroid carcinoma (FTC), follicular variant of papillary thyroid carcinoma (FVTC), and follicular thyroid adenoma (FA) definitive distinction of FA from FVTC, low-grade or well-differentiated FTC may be difficult or even impossible $[16,17,18]$.

Current molecular approaches such as microarray analysis or proteomic studies were demonstrated to successfully dis- 
criminate between FA and follicular neoplasms [19, 20, 21, $22,23,24,25,25]$. However these methods are very expensive, time consuming and difficult to translate into clinical practice. Also immunochemical analysis and histo(cyto)pathological examinations are limited by tissue cellularity, shape and variable number of follicular cells, application of optimal antibodies and substrates or even needle size $[27,28,29,30,31,32]$.

Our previous studies demonstrated that ARE-binding protein AUF1 promotes thyroid carcinogenesis and may serve as a new additional marker for thyroid carcinoma progression [33]. Given that FNA biopsy samples may contain variable and limited number of thyroid epithelial cells and unwanted blood cells, we applied total tissue lysates obtained from surgical resection for investigation with specific AUF1 and HuR anti-sera. By employing western blot we tested the expression of these ARE-binding proteins in different thyroid specimens with a special focus on FA and FTC.

\section{Patients and methods}

Patients and tissue preparation. A total of 68 thyroid tissues, including 7 goiter tissues $(\mathrm{G}), 16$ follicular adenoma

Table 1. Thyroid tissues employed in this study.

\begin{tabular}{|c|c|c|c|c|c|c|c|c|c|}
\hline \multirow[t]{2}{*}{ No. } & \multirow[t]{2}{*}{ Tissue } & \multirow[t]{2}{*}{ pTNM } & \multicolumn{2}{|c|}{$\begin{array}{l}\text { Expression }(\%) \text { as } \\
\text { compared to positive } \\
\text { control }(\mathrm{C}+)\end{array}$} & \multirow[t]{2}{*}{ No. } & \multirow[t]{2}{*}{ Tissue } & \multirow[t]{2}{*}{ pTNM } & \multicolumn{2}{|c|}{$\begin{array}{c}\text { Expression }(\%) \text { as } \\
\text { compared to positive } \\
\text { control }(\mathrm{C}+)\end{array}$} \\
\hline & & & AUF1 & HuR & & & & AUF1 & HuR \\
\hline 1. & Goiter & & 2.54 & 3.26 & 35. & FTC & pT3N0M0 & 100.44 & 36.57 \\
\hline 2. & Goiter & & 2.55 & 2.75 & 36. & FTC & pT3N0Mx & 128.36 & 28.93 \\
\hline 3. & Goiter & & 22.11 & 9.72 & 37. & FTC & pT2N1M0 & 120.6 & 56.78 \\
\hline 4. & Goiter & & 7.12 & 6.12 & 38. & FTC & $\mathrm{x}$ & 255.14 & 35.76 \\
\hline 5. & Goiter & & 4.48 & 3.21 & 39. & FTC & $\mathrm{x}$ & 237.46 & 138.04 \\
\hline 6. & Goiter & & 8.25 & 7.34 & 40. & FTC & pT3N1M1 & 163.67 & 57.24 \\
\hline \multirow[t]{2}{*}{7.} & Goiter & & 46.58 & 29.66 & 41. & FTC & pT4N0M0 & 67.82 & 53.98 \\
\hline & & & & & 42. & FTC & $\mathrm{x}$ & 48.89 & 20.78 \\
\hline 8. & Adenomatous Hyperplasia & & 145.77 & 47.31 & & & & & \\
\hline 9. & Adenoma & & 21.03 & 12.88 & 43. & PTC & pT2N0M0 & 93.83 & 38.83 \\
\hline 10. & Adenomatous Hyperplasia & & 38.31 & 30.35 & 44. & PTC & pT4N1M0 & 76.28 & 48.93 \\
\hline 11. & Adenoma & & 3.79 & 1.95 & 45. & PTC & pT1N0M0 & 82.64 & 144.24 \\
\hline 12. & Adenoma & & 4.08 & 4.86 & 46. & PTC & pT3NxM0 & 50.12 & 28.72 \\
\hline 13. & Adenoma & & 20.07 & 12.88 & 47. & PTC & pT4N1M0 & 85.97 & 58.59 \\
\hline 14. & Adenoma & & 1.62 & 3.38 & 48. & PTC & pT4NxMx & 38.61 & 33.51 \\
\hline 15. & Adenoma & & 1.42 & 3.15 & 49. & PTC & pT4N1Mx & 100.34 & 33.54 \\
\hline 16. & Adenoma & & 7.87 & 5.03 & 50. & PTC & pT4N1Mx & 137.56 & 80.00 \\
\hline 17. & Adenoma & & 6.48 & 0 & 51. & PTC & pT4N1Mx & 29.51 & 16.06 \\
\hline 18. & Adenoma & & 12.87 & 0 & 52. & PTC & pT4pN1Mx & 101.67 & 36.38 \\
\hline 19. & Adenoma & & 4.74 & 0 & 53. & PTC & pT2N1Mx & 90.70 & 38.61 \\
\hline 20. & Adenomatous Hyperplasia & & 70.19 & 49.29 & 54. & PTC & pT1N0M0 & 313.91 & 95.76 \\
\hline 21. & Adenoma & & 0 & 0 & 55. & PTC & pT4N1Mx & 86.10 & 57.72 \\
\hline 22. & Adenoma & & 0 & 0 & & & & & \\
\hline \multirow[t]{2}{*}{23.} & Adenomatous Hyperplasia & & 11.99 & 10.94 & 56. & UTC & pT3N1Mx & 66.06 & 44.37 \\
\hline & & & & & 57. & UTC & pT3N1M1 & 106.85 & 82.80 \\
\hline 24. & FTC & pT4N0Mx & 102.62 & 48.58 & 58. & UTC & pT4NxMx & 31.82 & 3.92 \\
\hline 25. & FTC & pT4NxMx & 52.7 & 55.60 & 59. & UTC & pT3NxMx & 121.15 & 77.37 \\
\hline 26. & FTC & pT2N1M1 & 19.46 & 23.94 & 60 & UTC & pT4 & 88.75 & 19.86 \\
\hline 27. & FTC & pT3NxMx & 23.27 & 40.02 & 61. & UTC & pT4N0M1 & 112.39 & 70.18 \\
\hline 28. & FTC & $\mathrm{x}$ & 110.2 & 53.82 & 62 & UTC & pT4N1Mx & 104.72 & 104.66 \\
\hline 29. & FTC & pT4N1M0 & 69.24 & 78.13 & 63. & UTC & $\mathrm{T} 4$ & 60.95 & 36.56 \\
\hline 30. & FTC & pT4N0Mx & 29.42 & 21.55 & 64. & UTC & T4NxM1 & 80.67 & 93.15 \\
\hline 31. & FTC & pT3NxM0 & 118.27 & 175.23 & 65. & UTC & T4N1 & 49.89 & 46.94 \\
\hline 32. & FTC & pT3NxM0 & 30.16 & 26.72 & 66. & UTC & T4N0M1 & 114.96 & 72.51 \\
\hline 33. & FTC & pT2N0Mx & 14.61 & 15.34 & 67. & UTC & $\mathrm{x}$ & 39.86 & 59.60 \\
\hline 34. & FTC & pT3N1Mx & 47.57 & 40.92 & 68. & UTC & $\mathrm{T} 4$ & 175.08 & 135.49 \\
\hline
\end{tabular}


(FA) including 4 adenomatous hyperplasia tissues (AH), 19 follicular thyroid carcinomas (FTC), 13 papillary thyroid carcinomas (PTC) and 13 undifferentiated thyroid carcinomas (UTC), were collected directly from patients treated in the time interval from 1994 to 2011 in the Department of Surgery of the Martin-Luther-University Halle, by surgical resection. Pathological diagnosis of tissue sections was confirmed with haematoxylin and eosin staining. For 4 FTCs and 1 UTC sample the pTNM status was unknown (Table 1). All tissues were snap frozen in liquid nitrogen and stored at $-80^{\circ} \mathrm{C}$ for further proceedings. For protein extraction the tissues with known diagnosis and histological classification were homogenized 2 times $20 \mathrm{sec}$ at frequency of 2500rpm with Mikro-Dismembrator S (Braun Biotech, Melsungen, Germany). Homogenized tissues were incubated with extraction buffer containing 7M Urea, 2M Thiourea, 4\% CHAPS and 40mM DTT. Lysis was performed at room temperature for $30 \mathrm{~min}$, vortexing every $10 \mathrm{~min}$. Supernatants were transferred into new tubes and the rest of un-dissolved tissue debris was discarded. $20 \mu$ l of protein solution was applied for Bradford assay; the rest was stored at $-80^{\circ} \mathrm{C}$ until use. In order to avoid the possible interference of lysis buffer with protein assay components, the samples were precipitated with chloroform/methanol method and then dissolved in $100 \mathrm{mM}$ Tris prior to measurement. Total protein lysates obtained from FTC-133 cells representing follicular thyroid carcinoma, served as positive control and were prepared and handled the same way as tissue extracts. This study was approved by the ethical committee of the Martin Luther University, Faculty of Medicine, and all patients gave written consent.

Western blot analysis. Total protein lysates from tissues and FTC- 133 cells $(5 \mu \mathrm{g})$ were resolved on $12 \%$ polyacrylamide gels and blotted onto PVDF membranes (Amersham Biosciences/ GE Healthcare, Uppsala, Sweden). Blocking was performed in $5 \%$ non-fat milk powder in 1xTBS /Tween $20(0.1 \%)$ for $1 \mathrm{~h}$. After $3 \mathrm{x}$ washing with $1 \mathrm{xTBS} /$ Tween 20 , the membranes were incubated overnight with AUF1 (1:20000, Millipore, Schwalbach, Germany) and HuR H-280 (1:1000, Santa Cruz Biotechnology) anti-sera in blocking buffer. After washing steps, the secondary goat anti-rabbit sc-2004 (1:40000) antibody was used (Santa Cruz Biotechnology). Specific protein bands were visualised using the ECL Detection Kit (Amersham Biosciences). Densitometric evaluations of western blots were performed with Kodak Image Software 440 cf (Eastman Kodak). Expression of AUF1 was examined as total expression of all isoforms. The protein band representing positive control $(\mathrm{C}+)$ on each X-ray film analysed, was set as $100 \%$ and compared with other bands. Expression of AUF1 and HuR in all samples was normalised with b-actin. The protein expression is presented as \% of $\mathrm{C}+$. Detection of specific protein bands was repeated at least three times.

Immunofluorescence. Freshly cut cryo-embedded serial $6 \mu \mathrm{m}$ sections of all thyroid tissues were fixed in cold acetone for $10 \mathrm{~min}$. After 2 times washing with PBS/ Tween $20(0.1 \%)$, the cells were incubated overnight at $4^{\circ} \mathrm{C}$ with the rabbit polyclonal antibodies against AUF1 (1:1000, Millipore, Schwalbach, Germany) or HuR H-280 (1:200, Santa Cruz Biotechnology) diluted with Dako Antibody Diluent (Dako, Glostrup, Denmark). Negative control sections were exposed to the secondary antibody only and processed as described below. After $3 \times 10$ min washing in PBS/ Tween $20(0.1 \%)$, the cells were incubated for $1 \mathrm{~h}$ with a 1:200 dilution of TRITClabelled anti-rabbit secondary antibody. After $1 \times 10 \mathrm{~min}$ washing in PBS/ Tween 20 (0.1\%), the slides were incubated in a 1:100 dilution in PBS-T of Hoechst staining (Hoechst AG) for $1 \mathrm{~min}$. After 3x $10 \mathrm{~min}$ final washing steps in PBS/ Tween $20(0.1 \%)$, the slides were dried and covered with fluorescence mounting medium (Dako). Finally, the cells were photographed under light/fluorescence microscope (Axioplan 2, Zeiss, Jena, Germany).

Statistics. Statistical analysis was carried out with GraphPad Prism software. Two-sided t test and multiple comparisons within thyroid tissues including Bonferroni correction were applied and $p$ values ${ }^{*}<0.01,^{* *}<0.001$ and $^{* * *}<0.0001$ indicated statistical significance.

\section{Results}

Expression of AUF1 and HuR on immunofluorescent tissue sections. In order to assess the expression and localisation of both proteins, freshly cut thyroid tissues were stained with AUF1 and HuR anti-sera. As demonstrated in Fig. 1, both proteins were detected in all tissues investigated; however their expression varied between G, FA, and carcinoma tissues. G and FA demonstrated weaker and mostly nuclear expression of AUF1 and HuR as compared with strong, nucleo-cytoplasmic expression in carcinoma tissues.

Given that quantification of immunohistochemical slides is relatively difficult and depends on the subjective evaluation of the investigators, we focused further investigations on total thyroid tissue extracts by employment of western blots analysis. As FNA biopsies often contain variable and limited number of thyroid epithelial cells and unwanted blood cells, analysis of total protein obtained from surgical thyroid samples may be treated as FNA-comparable.

Expression of AUF1 and HuR on total tissue extracts. Protein lysates of thyroid tissues obtained from patients with known diagnosis were subjected for western blot analysis with specific AUF1 and HuR anti-sera (Fig. 2A). Similar to immunofluorescence studies, the expression of both proteins was noticeably weakly detected in G and FA in comparison with carcinoma tissues. Densitometric analysis of western blot results, revealed significant up-regulation of AUF1 and HuR in FTCs, PTCs and UTCs as compared with their low expression in FA and G (Table 1, Fig. 2B). The mean percentage expression for AUF1 in each histological subgroup was $13.38 \%$ $( \pm 15.65, \mathrm{G}), 21.89 \%$ ( \pm 36.84, FA), 91.57\% ( \pm 70.49, FTC), $99.01 \%( \pm 72.78$, PTC) and $83.77 \%$ ( \pm 46.14 , UTC). Analysis of HuR revealed following mean percentages: $8.87 \%( \pm 9.35$, G), $11.38 \%( \pm 16.14$, FA $), 53.83 \%$ ( \pm 42.01, FTC $), 54.68 \%( \pm$ 
36.26, PTC) and 60.53\% ( \pm 40.19 , UTC). Furthermore and more importantly, the expression level of AUF1 or HuR, or combination of both proteins allowed significant discrimination between FA and FTC. Interestingly, in 3 cases of AH the expression of both proteins was noticeably higher than in other FA tissues investigated. The expression of AUF1 and HuR within thyroid carcinoma tissues was high, but did not significantly differ between FTC, PTC and UTC. We did not observe any correlations between AUF1 and HuR expression and age, gender and pTNM status.

\section{Discussion}

In this study we identified two ARE-binding proteins, AUF1 and HuR, as novel indicators of the malignant state of thyroid epithelial cell. We found that the low levels of both proteins in benign and adenoma tissues are extremely high in thyroid carcinoma tissues. Furthermore, in addition to our previously published data $[33,34]$, we were able to quantify the expression of both proteins on total protein lysates obtained from homogenized thyroid resectants. More importantly, by employment of AUF1 and/or HuR anti-sera on human samples often containing other and unwanted types of the cells (i.e. blood cells), we could discriminate between FA and FTC of the thyroid gland. To our knowledge, this is the first report demonstrating that quantification of those both proteins, especially AUF1, may possess the diagnostic properties for thyroid samples. With regard to HuR expression, its increased levels were demonstrated for malignant tissues of kidneys, skin, brain, cervix, tongue, gingival, colon, breast, ovary and stomach as compared to corresponding controls $[35,36,37,38,39,40,41,42,43]$. However most of these results were obtained by employing immunohistochemistry, which is often limited due to the technical reasons such as the quality and type of the specimens and antibodies used. These are especially important for thyroid samples where the quality of cell-block preparations is crucial for reliable immunostaining. Previous studies demonstrated that optimal staining with galectin-3, broadly reported as thyroid biomarker, requires formalin-fixed and paraffin-embedded preparations, biotin-free detection systems and application of specific monoclonal antibodies. Additionally, the conventional thyroid smears were reported to be inadequate for galectin-3 purposes [29], but its diagnostic properties are
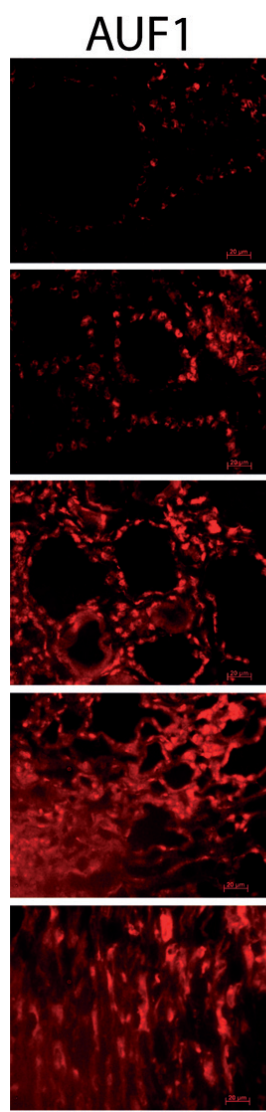
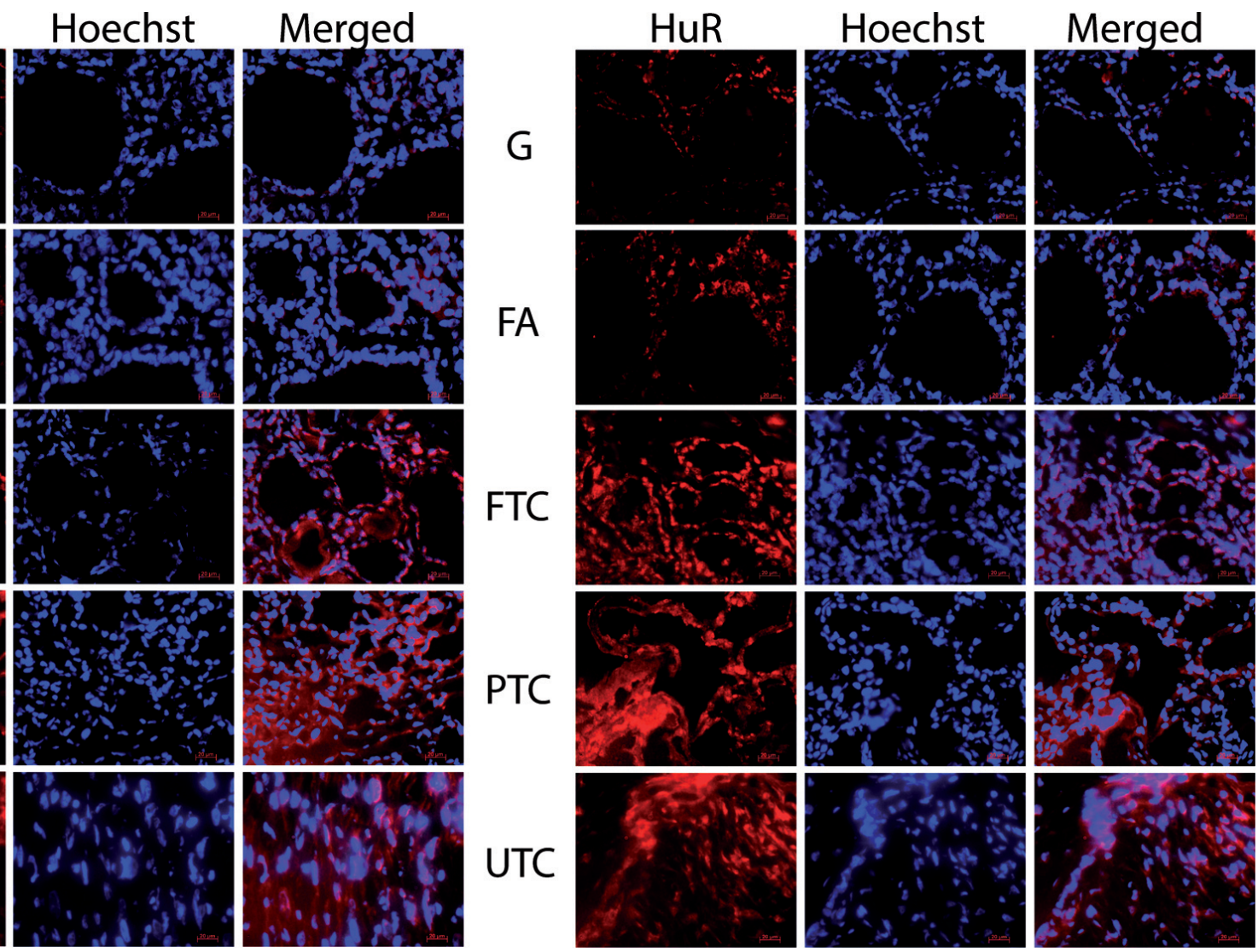

Figure 1. Immunofluorescence analysis of AUF1 and HuR expression on thyroid tissues. Frozen, freshly cut serial $6 \mu m$ cryosections were stained with specific AUF1 and HuR anti-sera, and visualised with rhodamine-labelled secondary antibody (red). The nuclei were stained with Hoechst dye (blue). Note weaker and mostly nuclear expression of AUF1 and HuR in G and FA and stronger, nucleo-cytoplasmic staining in carcinoma tissues. 
excellent on large-needle aspiration biopsy (LNAB) derived substrates [44]. Also the other markers including human mesothelial antigen (HBME-1), cytokeratin 19 (CK19), thyroid peroxidase (TPO) and keratan-sulphate (KS) or proteins related with energy metabolism such as alpha enolase (ENO1), glyceraldehyde-3-phosphate dehydrogenase (GAPDH), pyruvate kinase isoenzymes M1/M2 (PKM1/ M2) and transketolase (TKT) employed to surgical thyroid or FNAB samples were reported to possess the diagnostic potential $[45,22]$. Current investigations by Sponziello at al. revealed that employment of 4 proteins including peroxisomal proliferator-activated receptor- $\gamma$, serum deprivation response protein, osteoglycin and dipeptidase may support molecular discrimination between FTC and FA [46]. Also the employment of 5-gene classifier as demonstrated in study by Pfeifer at al. was successfully applied as a marker for FTC and FA in formalin-fixed paraffin-embedded samples [47]. Although the functional or biological rationale of the markers used in those studies remains not entirely understood for thyroid gland, they proved to be of a great accuracy.
A
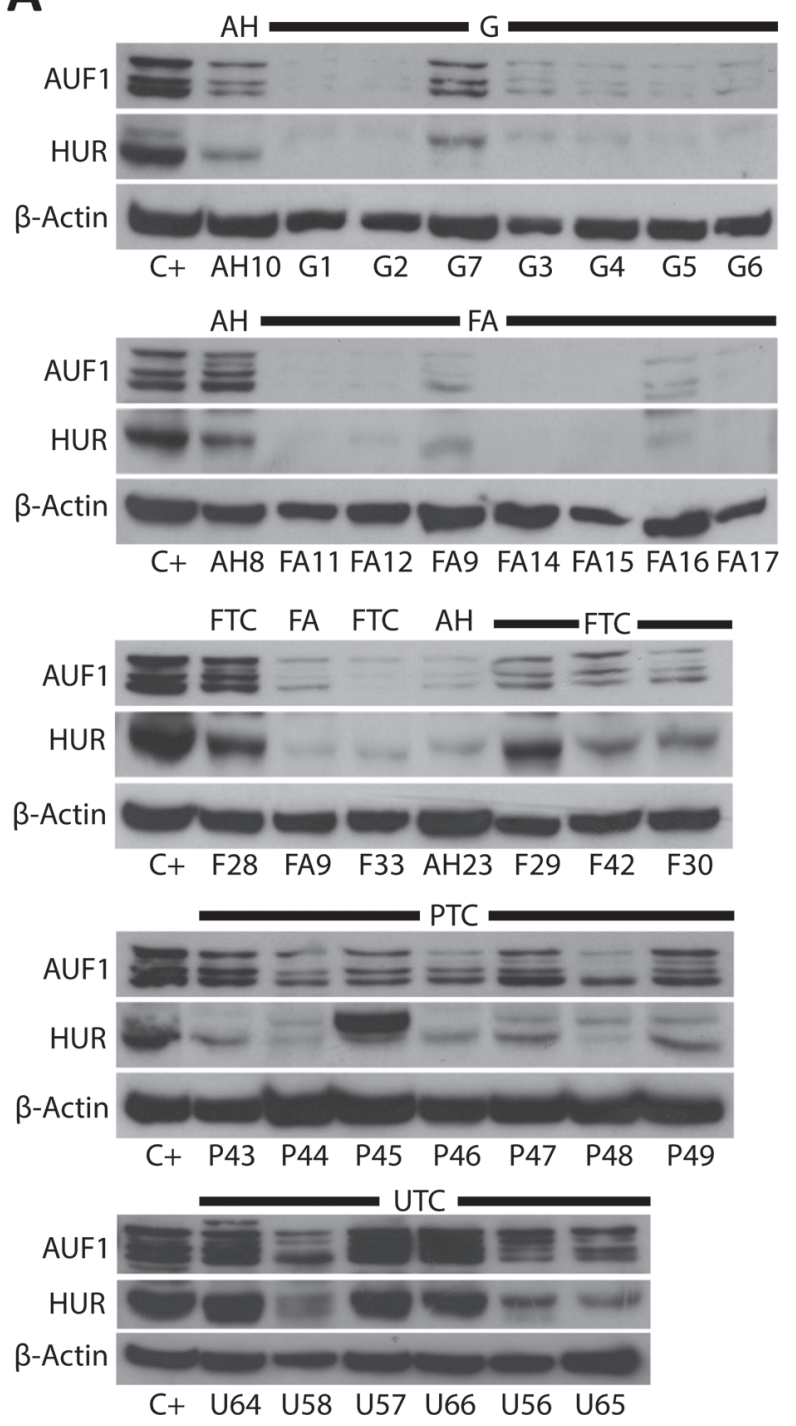

B

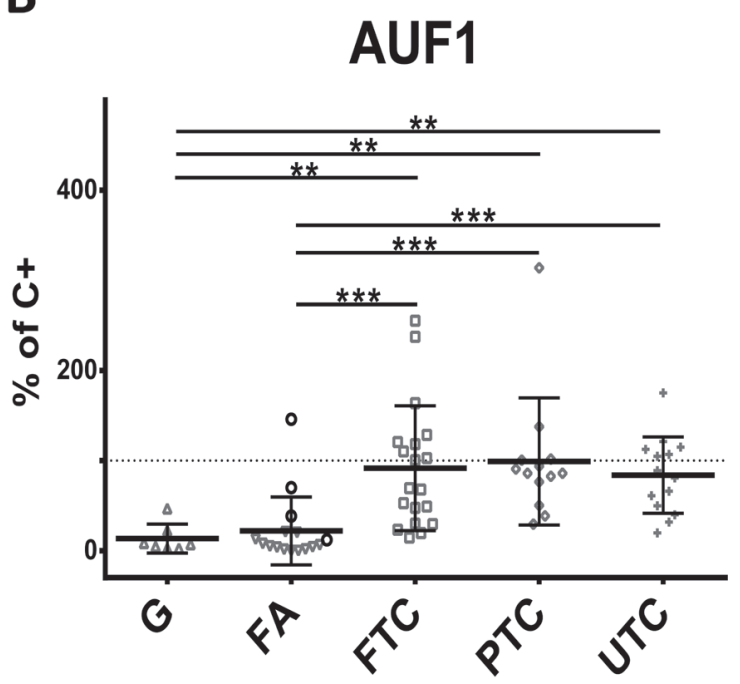

HuR

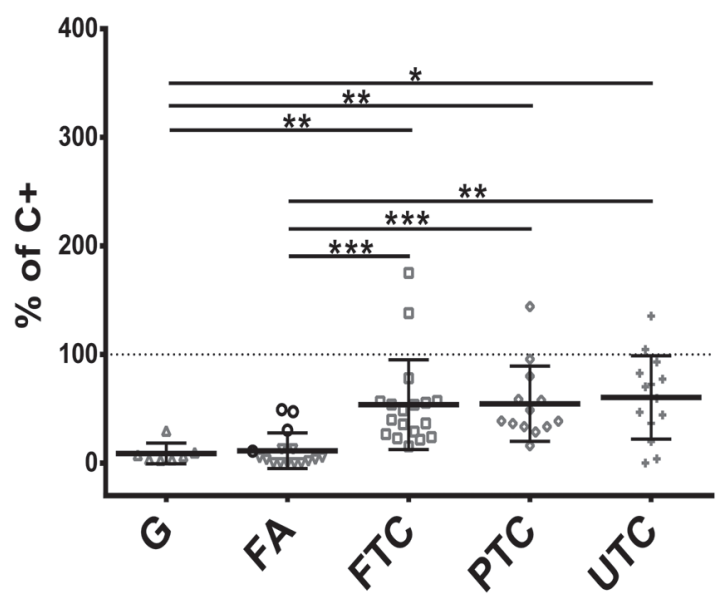

Figure 2. Western blot analysis performed on human thyroid samples. Total protein lysates obtained from goiter (G), follicular adenoma (FA), follicular thyroid carcinoma (FTC), papillary thyroid carcinoma (PTC), undifferentiated thyroid carcinoma (UTC) and FTC-133 cells were separated on polyacrylamide gels and blotted onto PVDF membranes. (A) Specific protein bands were detected with AUF1 and HuR anti-sera and visualised with ECL method on X-ray films. B-Actin served as normalising marker; C+, positive control; G1-G7, goiter; FA9, FA11, FA12, FA14-FA17, FA28, follicular adenoma; AH8, AH10, AH23, adenomatous hyperplasia; F28-F30, F33, F42, FTC; P43-P49, PTC; U56-U58, U64-U66, U69, UTC. The numbers after characters correspond to the numbers presented in Table 1. (B) Densitometric evaluation of western blot. The levels of AUF1 and HuR are expressed as \% of positive control $(\mathrm{C}+)$ set as $100 \%$; Note that AUF1 was evaluated as total expression of all isoforms; Means \pm SD of $\%$ expression in all samples tested; Note that $4 \mathrm{AH}$ samples in FA are indicated as bold circles; ${ }^{*}<0.01,{ }^{* *}<0.001$ and ${ }^{* * *}<0.0001$ indicate statistical significance. 
In summary we report here that two ARE-binding proteins AUF1 and HuR are helpful to discriminate between benign and malignant thyroid lesions, but with this advantage that the quality of cytological preparation was omitted. This alternative immuno-analysis with both proteins performed on FNA-comparable surgical samples does not replace, but may support the conventional cytological investigations and future development of a quick thyroid diagnostic test, especially on thyroid smears for which definitive diagnosis is difficult.

The promising findings of this study were performed on relatively small collective but justify further investigations on larger cohort of the patients.

Acknowledgements: We would like to thank Ms. Kathrin Hammje for excellent technical assistance in creation of this manuscript. This study was partly supported by Deutsche Forschungsgemeinschaft (DFG): grant No. HO 1813/12-1

\section{References}

[1] PARKER SL, TONG T, BOLDEN S, WINGO. PA1997 Cancer statistics. CA Cancer J Clin 1997; 47: 5-27. http://dx.doi. org/10.3322/canjclin.47.1.5

[2] CARPI A, MECHANICK JI, SAUSSEZ S, NICOLINI A. Thyroid tumor marker genomics and proteomics: diagnostic and clinical implications. J Cell Physiol 2010; 224: 612-619. http://dx.doi.org/10.1002/jcp.22187

[3] BERMANO G, ARTHUR JR, HESKETH JE. Selective control of cytosolic glutathione peroxidase and phospholipid hydroperoxide glutathione peroxidase mRNA stability by selenium supply. FEBS Lett 1996; 387: 157-160. http://dx.doi. org/10.1016/0014-5793(96)00493-0

[4] BERNSTEIN P, ROSS J. Poly(A), poly(A) binding protein and the regulation of mRNA stability. Trends Biochem Sci 1989; 14: 373-377. http://dx.doi.org/10.1016/0968-0004(89)90011-X

[5] OWEN D, KUHN LC. Noncoding 3'sequences of the transferrin receptor gene are required for mRNA regulation by iron. EMBO J 1987; 6: 1287-1293.

[6] MENON MP, KHAN A. Micro-RNAs in thyroid neoplasms: molecular, diagnostic and therapeutic implications. J Clin Pathol 2009; 62: 978-985. http://dx.doi.org/10.1136/ jcp.2008.063909

[7] BRAUN J, HOANG-VU C, DRALLE H, HUTTELMAIER S. Downregulation of microRNAs directs the EMT and invasive potential of anaplastic thyroid carcinomas. Oncogene 2010; 29: 4237-4244. http://dx.doi.org/10.1038/onc.2010.169

[8] FINDEIS-HOSEY JJ, XU H. The use of insulin like-growth factor II messenger RNA binding protein-3 in diagnostic pathology. Hum Pathol 2010; 42: 303-314. http://dx.doi. org/10.1016/j.humpath.2010.06.003

[9] KHABAR KS. Post-transcriptional control during chronic inflammation and cancer: a focus on AU-rich elements. Cell Mol Life Sci 2010; 67: 2937-2955. http://dx.doi.org/10.1007/ $\underline{\mathrm{s} 00018-010-0383-\mathrm{X}}$
[10] HINMAN MN, LOU H. Diverse molecular functions of $\mathrm{Hu}$ proteins. Cell Mol Life Sci 2008; 65: 3168-3181. http://dx.doi. org/10.1007/s00018-008-8252-6

[11] LOPEZ DE SILANES I, ZHAN M, LAL A, YANG X, Gorospe M. Identification of a target RNA motif for RNA-binding protein HuR. Proc Natl Acad Sci U S A 2004; 101: 2987-2992. http://dx.doi.org/10.1073/pnas.0306453101

[12] MAZAN-MAMCZARZ K, KUWANO Y, ZHAN M, WHITE EJ, MARTINDALE JL, et al. Identification of a signature motif in target mRNAs of RNA-binding protein AUF1. Nucleic Acids Res 2009; 37: 204-214. http://dx.doi.org/10.1093/nar/ gkn929

[13] ARAO Y, KIKUCHI A, KISHIDA M, YONEKURA M, INOUE A et al. Stability of A+U-rich element binding factor 1 (AUF1)-binding messenger ribonucleic acid correlates with the subcellular relocalization of AUF1 in the rat uterus upon estrogen treatment. Mol Endocrinol 2004; 18: 2255-2267. http://dx.doi.org/10.1210/me.2004-0103

[14] ZUCCONI BE, WILSON GM. Modulation of neoplastic gene regulatory pathways by the RNA-binding factor AUF1. Front Biosci (Landmark Ed) 2011; 16: 2307-2325. http://dx.doi. org/10.2741/3855

[15] MOORE AE, CHENETTE DM, LARKIN LC, SCHNEIDER RJ. Physiological networks and disease functions of RNAbinding protein AUF1. Wiley Interdiscip Rev RNA 2014; 5: 549-564. http://dx.doi.org/10.1002/wrna.1230

[16] GOLDSTEIN RE, NETTERVILLE JL, BURKEY B, JOHNSON JE. Implications of follicular neoplasms, atypia, and lesions suspicious for malignancy diagnosed by fine-needle aspiration of thyroid nodules. Ann Surg 2002; 235: 656-662. http:// dx.doi.org/10.1097/00000658-200205000-00007

[17] BRYSON PC, SHORES CG, HART C, THORNE L, PATEL $\mathrm{MR}$, et al. Immunohistochemical distinction of follicular thyroid adenomas and follicular carcinomas. Arch Otolaryngol Head Neck Surg 2008; 134: 581-586. http://dx.doi. org/10.1001/archotol.134.6.581

[18] SCHMID KW, FARID NR. How to define follicular thyroid carcinoma? Virchows Arch 2006; 448: 385-393. http://dx.doi. org/10.1007/s00428-006-0162-0

[19] BARDEN CB, SHISTER KW, ZHU B, GUITER G, GREENBLATT DY, et al. Classification of follicular thyroid tumors by molecular signature: results of gene profiling. Clin Cancer Res 2003; 9: 1792-1800.

[20] CERUTTI JM, DELCELO R, AMADEI MJ, NAKABASHI C, MACIEL RM, et al. A preoperative diagnostic test that distinguishes benign from malignant thyroid carcinoma based on gene expression. J Clin Invest 2004; 113: 1234-1242. http:// dx.doi.org/10.1172/JCI19617

[21] WEBER F, TERESI RE, BROELSCH CE, FRILLING A, ENG C. A limited set of human MicroRNA is deregulated in follicular thyroid carcinoma. J Clin Endocrinol Metab 2006; 91: 3584-3591. http://dx.doi.org/10.1210/jc.2006-0693

[22] TROJANOWICZ B, SEKULLA C, LORENZ K, KOHRLE J, FINKE R, et al. Proteomic approach reveals novel targets for retinoic acid-mediated therapy of thyroid carcinoma. Mol Cell Endocrinol 2010; 325: 110-117. http://dx.doi.org/10.1016/j. mce.2010.05.022 
[23] NETEA-MAIER RT, HUNSUCKER SW, HOEVENAARS BM, HELMKE SM, SLOOTWEG PJ, et al. Discovery and validation of protein abundance differences between follicular thyroid neoplasms. Cancer Res 2008; 68: 1572-1580. http://dx.doi.org/10.1158/0008-5472.CAN-07-5020

[24] BRAUNSCHWEIG T, KASERER K, CHUNG JY, BILKE S, KRIZMAN D, et al. Proteomic expression profiling of thyroid neoplasms. Proteomics Clin Appl 2007; 1: 264-271. http:// dx.doi.org/10.1002/prca.200600381

[25] FOUKAKIS T, GUSNANTO A, AU AY, HOOG A, LUI WO, et al. A PCR-based expression signature of malignancy in follicular thyroid tumors. Endocr Relat Cancer 2007; 14: 381-391. http://dx.doi.org/10.1677/ERC-06-0023

[26] ALEXANDER EK, KENNEDY GC, BALOCH ZW, CIBAS ES, CHUDOVA D, et al. Preoperative diagnosis of benign thyroid nodules with indeterminate cytology. N Engl J Med 2012; 367: 705-715. http://dx.doi.org/10.1056/NEJMoa1203208

[27] MILLS LJ, POLLER DN, YIANGOU C Galectin-3 is not useful in thyroid FNA. Cytopathology 2005; 16: 132-138. http:// dx.doi.org/10.1111/j.1365-2303.2005.00213.x

[28] BARTOLAZZI A, GASBARRI A, PAPOTTI M, BUSSOLATI G, LUCANTE T, et al. Application of an immunodiagnostic method for improving preoperative diagnosis of nodular thyroid lesions. Lancet 2001; 357: 1644-1650. http://dx.doi. org/10.1016/S0140-6736(00)04817-0

[29] BARTOLAZZI A, ORLANDI F, SAGGIORATO E, VOLANTE M, ARECCO F, et al. Galectin-3-expression analysis in the surgical selection of follicular thyroid nodules with indeterminate fine-needle aspiration cytology: a prospective multicentre study. Lancet Oncol 2008; 9: 543-549. http:// dx.doi.org/10.1016/S1470-2045(08)70132-3

[30] FREITAS BC, CERUTTI JM Genetic markers differentiating follicular thyroid carcinoma from benign lesions. Mol Cell Endocrinol 2010; 321: 77-85. http://dx.doi.org/10.1016/j. mce.2009.11.008

[31] CARPI A, NICOLINI A, MARCHETTI C, IERVASI G, ANTONELLI A, et al. Percutaneous large-needle aspiration biopsy histology of palpable thyroid nodules: technical and diagnostic performance. Histopathology 2007; 51: 249-257. http://dx.doi.org/10.1111/j.1365-2559.2007.02764.x

[32] CARPI A, ROSSI G, COSCIO GD, IERVASI G, NICOLINI A, et al. Galectin-3 detection on large-needle aspiration biopsy improves preoperative selection of thyroid nodules: a prospective cohort study. Ann Med 2010; 42: 70-78. http:// dx.doi.org/10.3109/07853890903439778

[33] TROJANOWICZ B, BRODAUF L, SEKULLA C, LORENZ $\mathrm{K}$, FINKE R, et al. The role of AUF1 in thyroid carcinoma progression. Endocr Relat Cancer 2009; 16: 857-871. http:// dx.doi.org/10.1677/ERC-08-0234

[34] TROJANOWICZ B, DRALLE H, HOANG-VU C AUF1 and HuR: possible implications of mRNA stability in thyroid function and disorders. Thyroid Res 2011; 4: Suppl 1: S5. http:// dx.doi.org/10.1186/1756-6614-4-S1-S5

[35] LIM SJ, KIM HJ, KIM JY, PARK K, LEE CM. Expression of HuR is associated with increased cyclooxygenase- 2 expression in uterine cervical carcinoma. Int J Gynecol Pathol 2007; 26: 229234. http://dx.doi.org/10.1097/01.pgp.0000236946.82334.07
[36] BROSENS LA, KELLER JJ, POHJOLA L, HAGLUND C, MORSINK FH, et al. Increased expression of cytoplasmic HuR in familial adenomatous polyposis. Cancer Biol Ther 2008; 7: 424-427. http://dx.doi.org/10.4161/cbt.7.3.5417

[37] KOLJONEN V, BOHLING T, HAGLUND C, RISTIMAKI A. Expression of HuR in Merkel cell carcinoma and in normal skin. J Cutan Pathol 2008; 35: 10-14.

[38] DANILIN S, SOURBIER C, THOMAS L, ROTHHUT S, LINDNER V, et al. von Hippel-Lindau tumor suppressor gene-dependent mRNA stabilization of the survival factor parathyroid hormone-related protein in human renal cell carcinoma by the RNA-binding protein HuR. Carcinogenesis 2009; 30: 387-396. http://dx.doi.org/10.1093/carcin/bgn275

[39] RONKAINEN H, VAARALA MH, HIRVIKOSKI P, RISTIMAKI A. HuR expression is a marker of poor prognosis in renal cell carcinoma. Tumour Biol 2011; 32: 481-487. http:// dx.doi.org/10.1007/s13277-010-0141-6

[40] HEINONEN M, HEMMES A, SALMENKIVI K, ABDELMOHSEN K, VILEN ST, et al. Role of RNA binding protein HuR in ductal carcinoma in situ of the breast. J Pathol 2011; 224: 529-539. http://dx.doi.org/10.1002/path.2889

[41] BOLOGNANI F, GALLANI AI, SOKOL L, BASKIN DS, MEISNER-KOBER N. mRNA stability alterations mediated by HuR are necessary to sustain the fast growth of glioma cells. J Neurooncol 2012; 106: 531-542. http://dx.doi.org/10.1007/ s11060-011-0707-1

[42] YUAN Z, SANDERS AJ, YE L, JIANG WG. HuR, a key posttranscriptional regulator, and its implication in progression of breast cancer. Histol Histopathol 2010; 25: 1331-1340.

[43] KAKUGUCHI W, KiTAMURA T, KUROSHIMA T, ISHIKAWA M, KITAGAWA Y, et al. HuR knockdown changes the oncogenic potential of oral cancer cells. Mol Cancer Res 2010; 8: 520-528. http://dx.doi.org/10.1158/1541-7786.MCR09-0367

[44] CARPI A, NACCARATO AG, IERVASI G, NICOLINI A, BEVILACQUA G, et al. Large needle aspiration biopsy and galectin-3 determination in selected thyroid nodules with indeterminate FNA-cytology. Br J Cancer 2006; 95: 204-209. http://dx.doi.org/10.1038/sj.bjc.6603232

[45] SAGGIORATO E, DE POMPA R, VOLANTE M, CAPPIA $S$, ARECCO F, et al. Characterization of thyroid ,follicular neoplasms in fine-needle aspiration cytological specimens using a panel of immunohistochemical markers: a proposal for clinical application. Endocr Relat Cancer 2005; 12: 305-317. http://dx.doi.org/10.1677/erc.1.00944

[46] SPONZIELLO M, LAVARONE E, PEGOLO E, DI LORETO C, PUPPIN C, et al. Molecular differences between human thyroid follicular adenoma and carcinoma revealed by analysis of a murine model of thyroid cancer. Endocrinology 2013; 154: 3043-3053. http://dx.doi.org/10.1210/en.2013-1028

[47] PFEIFER A, WOJTAS B, OCZKO-WOJCIECHOWSKA M, KUKULSKA A, CZARNIECKA A, et al. Molecular differential diagnosis of follicular thyroid carcinoma and adenoma based on gene expression profiling by using formalin-fixed paraffin-embedded tissues. BMC Med Genomics 2013; 6: 38. http://dx.doi.org/10.1186/17558794-6-38 